\title{
5
}

\section{Social Change and Generational Disparity: Education, Violence, and Precariousness in the Life Story of a Young Moroccan Activist}

\author{
Christoph H. Schwarz
}

\section{Introduction}

In this chapter, I argue for generational analysis as a tool for researching change. Through a focus on the empirical subject of intergenerational relationships in life stories, and particularly on processes of intergenerational transmission, social change becomes empirically accessible as narrated patterns of social interaction. When we analyze interviewees' appropriation and reinterpretation of narratives, norms, and resources passed on to them by older generations, and how they situate themselves in a generation or generational unit, in Mannheim's (1952) sense, we can reconstruct the pivotal questions that define their generational

\footnotetext{
The author would like to thank Lena Inowlocki and the editors of this volume for helpful comments on an earlier version of this chapter.
}

\section{H. Schwarz $(\varangle)$}

Institute for Social Research, Goethe University Frankfurt a.M., Frankfurt, Germany

e-mail: schwarz@em.uni-frankfurt.de 
actuality (Generationszusammenhang) in comparison to that of the older generation. Regarding methodology, life stories or narrative biographical interviews (Bertaux 1997; Rosenthal 1995; Schütze 1977) are adequate tools for analyzing intergenerational dynamics as well as for discovering the potential spaces within which the interviewee can actively and deliberately participate in or resist social change, rather than being the object of social change. The particular pattern of the biographical process structures that are conveyed through an interviewee's life story shed light on the material and structural constraints to, and the subjective experience of, social change: is change something that is suffered and must be accepted or adapted to? What are the resources, spaces, situations, and, most of all, relationships that allow individuals to consider themselves legitimate and capable agents of social change? Regarding political socialization and political participation, i.e., activism in social movements: do the interviewees present their activism precisely as a necessary break from the political or cultural traditions of their families or older generations in general, or as a "mission" imposed on them by their family or community? What significant others are relevant in the process of political engagement or disengagement, and what is their generational position?

Below, I present the case of a young Moroccan activist engaged with two social movements which, compared to the so-called Arab Spring protests of 2011, have received relatively little attention from the Western public; namely, the unemployed graduates' movement and the Amazigh movement. ${ }^{1}$ The pattern that the analysis will carve out can also be found in other interviews I conducted, but this case epitomizes it in particular drastic manner. I present this case to illustrate a particular constellation

\footnotetext{
${ }^{1}$ Some decades ago, the Amazigh movement was mainly referred to as "Berber movement", whereas now many activists reject the term "berber" for its pejorative implications and instead now refer to themselves as Imazighen (the plural of Amazigh, which literally translated means "free person"). Activists consider themselves the heirs of the indigenous population of the Maghrib who inhabited the region before the Arab Muslim invasion in the seventh century. Their language, Tamazight, a language of the Afro-Asian family that occurs in Morocco with three regional varieties, is often referred to as the strongest marker of difference from Arab cultural identity. The Moroccan Amazigh movement, which has developed as a result of social and cultural cleavages over the last decades, is a cultural and political nationalist movement that opposes the project of a pan-Arab or Islamist hegemony and the concomitant social exclusion and marginalization of the Amazigh population (Aït Mous 2011; Maddy-Weitzman 2011).
} 
of intergenerational relationships that can be characterized as a generational disparity. In this constellation, intergenerational relationships are characterized by a particular alienation between the generations, in the sense of incommunicability concerning key aspects of their everyday life, for instance the understanding of politics and the moral economy of political engagement or disengagement. Accordingly, members of the younger generation often describe social change as an experience of estrangement from the older generation, often narrated as a trajectory of suffering (Schütze and Riemann 1991): key aspects of the younger generation's social situation are significantly different to that of their elders, and the symbolic, economic, and social resources that the older generation could pass on do not help the younger generation to deal with social change, i.e., to make ends meet economically, resist politically, or make sense of their situation and attain agency. Instead, they have to rely primarily on networks of trust that they develop among members of their own generational unit. However, this disparity does not have to be definite and permanent, and it does not necessarily entail the breaking up of an intergenerational relationship in all its aspects. In the case discussed here, generational disparity mainly refers to differing processes of political socialization that result in unreconcilable perspectives on politics; it seems particularly relevant in the context of the production of an urban precariat constituted of the relatively well-educated sons and daughters of peasants, artisans, and nomads from rural Morocco (Schwarz 2017; Standing 2011).

\section{Intergenerational Transmission as a Subject of Life Stories}

Time constraints, material limitations, and academic obligations can make undertaking qualitative long-term studies difficult for researchers who study social and political transformation (see Berriane, Derks, Kreil, Lüddeckens in the introduction to this volume). The life story, or narrative biographical interview (Bertaux 1997; Riemann 1987; Rosenthal 1993, 2009; Schütze 1977) offers an appropriate methodological approach to tackle this problem, since the data produced here allow the 
inclusion of particularly long units of time-the lifetime of the interviewee up to the time of the interview - and can be retrieved in relatively short periods of time (Apitzsch et al. 2008). The subject of social change has been at the core of life-story research since its inception (Thompson 1981), just as questions of intergenerational relations and transmission, particularly regarding social mobility and precariousness (Benei 2010; Delcroix 2005). However, in many cases the notion of "generation" is reduced to familial generations, thus leaving aside other institutional settings of interest (Bertaux and Thompson 1993).

Furthermore, biographical research appears to be the most advanced way of tackling the "biographical ideology" (Bertaux 1976, 1997, 41) that Bourdieu (2004) later criticized so prominently as "biographical illusion", before making extensive use of life stories himself (Bourdieu 1993b). While the illusion of the self as a coherent entity, and of coherent life courses, is at play just as much in other forms of qualitative and quantitative research, the biographical approach has arguably theorized this effect in a particular explicit reflection: in order to make the interviewer understand how one thing has led to another and how she or he has become the person interviewed, the interviewees have to deal with the constraints of their narrations' own dynamic. In theorizing these constraints, as forces shaped by the structural logic of narrations as well as by hegemonic social norms, the postulate of coherence and comprehensibility, biographical research offers criteria and tools to analyze their effects. $^{2}$

In a mode of horizontal comparison within my sample I have chosen the case presented below as it represents the life story that made me conceptualize and contextualize generational disparity as a particular type of intergenerational dynamic set apart from types more strongly characterized by conflict or negotiation between members of different generations, or by a clear acceptance of the elements that have been passed on to younger generations (Schwarz 2019).

\footnotetext{
${ }^{2}$ The narrator in this sense is by no means a unit of analysis that is deemed permanent. Authors like Riemann (1987), who interviewed psychiatric patients, have done much to show the social suffering that is produced when individuals are no longer capable of fulfilling these norms of subjective coherence.
} 
When conducting the interview, I largely followed the standard procedure as outlined by Schütze (1977) and Riemann (1986), that is, after asking the interviewee to tell me his life story I did not interrupt his narration but listened until he had finished. Then, at first, I only asked questions about subjects that he had brought up himself, and only at the end added external questions on subjects not yet addressed by the interviewee. I aimed to formulate my questions in a way that would produce further narration rather than explanations or argumentation. Most of my internal and external questions were concerned with intergenerational relationships and political socialization.

When I present the case in the next section, I first "zoom in" and start with a rather detailed narrative analysis of the intergenerational relationships evident in two initial passages of the interview that seem emblematic of the further course of events; I then use this analysis to briefly introduce key concepts of narrative biographical analysis. In the subsequent sections, I "zoom out"; that is, based on a more condensed summary of the interviewee's subsequent life story, I present these first findings in relation to recurring patterns in and general characteristics of the interview.

\section{Interview: Shafik}

Shafik ${ }^{3}$ is the oldest son of an Amazigh nomad family from the High Atlas. He has six sisters and two brothers. Two of his older and two of his younger sisters are already married and his older brother works as a shepherd; he was the first of the family to attend school. Two of his younger sisters and his younger brother are currently attending school, living in the house of their maternal grandparents, while his parents continue to "live in the desert," as he says. His grandparents, parents, and older siblings are illiterate. Shafik is moreover the first and, so far, the only member of his nuclear family to go to university. He graduated with a B.A. and an M.A. in mathematics, and is currently writing his

\footnotetext{
${ }^{3}$ All the names of interviewees and others mentioned in the interview, and all local references are pseudonyms to guarantee anonymity.
} 
Ph.D. in the same discipline. At the time of the interview in autumn 2014, he was 32 years old.

\section{The First Day of School as an Emblematic Scene}

When asked to tell his life story, Shafik first introduces himself by name and nickname and then describes himself as "the son of a nomad," saying: "I'm not from a particular city, town or district; I was born in the desert. I don't exactly remember the place or its name, but it was close to Ouarzazate." He recounts how three days after his birth, his family traveled to a nearby city where he "celebrated his seventh day." Due to drought, his family had to move to different regions several times, and he mentions some respective childhood memories without going into detail. He relates how when he was seven, his father announced one day that he was taking him to live in his grandparents' house in another city so that he could attend elementary school. He says that it was quite hard to leave his parents and siblings, but when they told him that he would soon find new friends in school and when he "left the tent to live in a house and when I watched television for the first time," he felt encouraged, as he says. He recounts how his father took him to school on his first day to register him:

I started my first day. I went to the school with my father for the registration ... after a short while my dad left and, well, me-, I stayed. Well, I registered ... this is the only time that my father, that he visited my school, this is the only time in my life that my father-, well, that he took me to school, that was on the first day, to register me. ${ }^{4}$

If we interpret this excerpt using narrative analysis according to Schütze (1977), this passage represents a narration in the strict sense of the term: Shafik contextualizes the scene by mentioning a particular place (school) and time (his first day at school), which marks this experience as a onetime event and linguistically sets this passage apart from others that report or describe everyday repeated interactions, or from passages in which the

${ }^{4}$ This and all other quotes translated from French by the author. 
interviewee argues, i.e., gives reasons for his decisions, explains assumed causal relations, or presents his own normative assumptions and theories. And unlike argumentations or descriptions, the narration of one-time events usually presents turning points in the course of the interviewee's life story, critical junctures that often mark a shift from one biographical process to another. In the interview, these are functionally relevant to understanding how the interviewee became the person who is now talking to the interviewer. Accordingly, on a micro-level they are the prime data on which biographical analysis usually focuses. If similar patterns of biographical change are found in other cases in the sample they might allow for an analytical abstraction and feed into larger debates on social change, for example as typical school career patterns at certain intersections of class, gender and ethnicity in a given social context.

Here, the subject of the narration is Shafik's first day at school, and it is narrated first and foremost as a story of an abrupt separation; the child's loneliness is highlighted by stating that his father left "and I stayed," followed by the reiterated emphasis that this was the only time in his life that his father ever visited him at school or took him to school. At one point it sounds as if Shafik even had to register himself ("I registered"), his father having already left before this actual administrative procedure occurred. Such a confusion of agencies and the slight shake-up of the chronology conveys a rather fuzzy picture of his father as a subject and a decision-maker. This, in turn, indicates that the child did not actually understand the meaning or "message" implicit in his father's action, and it seems that his father did not give further explanations, or maybe did not even know them himself. In general, the narration thus conveys the impression that Shafik's father is a person who feels out of place in this institution at which he has decided to register his son. In this passage his father only appears as a significant other regarding formal education, in that he was the person who rather abruptly took the decision to send Shafik to school. But he is not described as someone who passed on any relevant knowledge that could have helped his son on his way. The father obviously decided that his son must take up a life project very different from his own, for which he could hardly offer him guidance or symbolic resources. Such a constellation bears certain tensions and contradictions for the younger generation, which, according to Bourdieu (1993a, 508) 
even imposes a "murder of the father accomplished at the father's injunction" on the member of the younger generation. All the characteristics of the passage in question can thus be read as strong markers of intergenerational disparity, since the passage is characterized by incommunicability and an impasse in intergenerational transmission. It thus anticipates a certain estrangement between members of two familial generations with regard to a key aspect of Shafik's biography, that of formal education. This dynamic becomes increasingly salient in the subsequent narrative.

\section{Peer Violence and Liminality}

Shafik continues his life story, implicitly describing how he felt different from others of his own generation-his classmates-who, unlike him, had "already seen a biro and a notebook." He recounts that having done very badly in the school exams to start with, he gradually started to produce better results. Most importantly, he describes his years in elementary school, and particularly his first weeks, as characterized by daily discrimination on the part of his classmates, who felt superior to a shepherd's son and frequently insulted him so that he often came into conflict [entrer en conflit] with them, suggesting that this was in the form of physical brawls. As the life story continues, the separation, loneliness, and estrangement conveyed in the passage about his registration are exacerbated by his peers' behavior. By persistently addressing Shafik as "the son of a shepherd" - an obvious fact, but here used as an insult-they are metaphorically sending him "back to the desert, where he belongs."

These insults were hard to bear, and after some days Shafik told his aunt, who also lived at his grandparents' house, what he was suffering. She would then come to see him at school and intervene in a very resolute way:

It was the first day, or, well, the first week. I told my aunt. So she came to school and came to see me in class. I'm fighting with [this other pupil]; she slapped [him], she gave him a good slap [...] Yes, she slapped this pupil, so the teacher came and told her 'You don't have the right to slap my pupils in class; I'm in charge here'. Anyway, the situation calmed down, and at night, well, at night again, this pupil's mother comes [to 
our house]. She comes and she says, well, that my aunt, she'd slapped this pupil, and the mother of this pupil, she wants to fight [entrer en conflit avec] my grandmother. My grandmother tells her 'I'm an old woman, so if we fight and you win that wouldn't be a real victory for you anyway. Just wait, I'll call one of my daughters-she's your age, so you'll see, so you can...' Well, this made a strong impression on me [cette idée m'a resté dans ma tête], since I-, well, I was watching from a window to see what was going on. Well, the first days and months were like that: every day, every week there was a problem of this kind, either with the pupils or with others. In any case, my aunt and my grandmother always defended me; always, they would defend me.

In the narration, the aunt's sudden appearance is described as a resolute, physical intervention, without explanation, or any use of words, for that matter. His grandmother, on the other hand, engages in a verbal argument with the pupil's mother and discursively plays the cards of her social age and the authority that comes with it, additionally threatening to call one of her daughter's, one of whom had already proven that she had few qualms about resorting to physical violence.

In Shafik's life story, school is described as a hostile and very brutal place, characterized mainly by peer violence. Teachers do not appear as relevant others in this narration. An important indicator in this regard is the fact that throughout the entire interview, and in all of Shafik's narrations about school and university, the teacher who expelled his aunt from the school premises is the only educational member of staff that he mentions. Such negligence on behalf of the teachers indicates that the explicit discrimination by peers should not be read as the result of individual misdemeanor, or mere adolescent group dynamics, but rather as an echo that amplifies the often rather implicit institutional devaluation of his father's male life project. "Son of a shepherd," used as an insult, is intended to make Shafik feel out of place in this institution, by depreciating his social background and denying his capacity to participate in or contribute to social change, i.e., the grand narrative of development and educational progress with which school, as a modern, and modernizing institution is imbued. 
Analytically, the biographical process associated with Shafik's narration about his elementary school experience does not appear as a programmatic institutional process structure; that is, a process that passes through stages with explicit rules and a predictable outcome. Instead, it contains certain characteristics of a trajectory of suffering (Schütze and Riemann 1991), in the sense that the subject is increasingly losing control of his life until his aunt and grandmother step into the arena and confront not only the pupil, but also the pupil's mother. Although Shafik does not report any further verbal encouragement from his aunt or his grandmother during the course of the interview, these two illiterate women are obviously the most significant others in bringing an end to Shafik's trajectory of suffering in school, allowing him to regain a sense of agency in this institutional setting. The scenes of his aunt's intervention and the altercation between his grandmother and the pupil's mother also relate a process of intergenerational transmission, since the two women appear to provide him with a relevant example of struggle for respect and against discrimination. The confrontations with the pupil and his mother made a strong impression on Shafik (literally translated, "stayed in his head"), as he emphasizes above, highlighting their lasting relevance for him. In a later passage, Shafik mentions that after the first year in elementary school his marks improved, and afterwards he was among the top pupils in the class.

\section{Language and Collective Identity}

It is worth mentioning that at first Shafik does not seem to frame these experiences as racist discrimination, but rather as social discriminationthe crucial word at play here is "son of a shepherd." When I learned later in the interview that he was now an activist with the Amazigh movement I asked him when he had first identified himself as such. Shafik recalled the first time he heard an Amazigh word in the setting of an educational institution, during a geography lesson in high school. Until the early 2000s the Tamazight language had never been officially used in Moroccan schools, and French had been reserved for the field of natural sciences when the regime of the 1980s introduced a process 
of Arabization. Shafik was surprised that his family's preferred language was actually used in school, and that it was called Tamazight in this context, because in his region of origin they always referred to his native langue as chleuh, or tachelhit, as the local variety of Tamazight is called. According to Shafik, this experience in school left him with a fundamental question: "So I asked myself: "What am I? Am I Arab or not?" He relates how, when discussing the subject with one of his older cousins who was studying at university at the time, he heard about the Amazigh movement and its demands for the first time.

This personal experience and reinterpretation of linguistic differences seemed to act as a catalyst for Shafik to reflect upon his identity. It offers a particularly clear case of the repercussions of the Moroccan regime's project to Arabize the educational system on the one hand, and in reaction, the significance that the Amazigh movement attributes to language as the "the repository of Berber culture and history, and as an object that requires rescue, development, and elevated status" (Maddy-Weitzman 2011, 17).

It is telling that in this key scene in the discovery-or rather construction-of an individual's reference to collective identity and cultural belonging we hear nothing about intergenerational transmission, i.e., parents, grandparents, or teachers telling children about their traditions or passing on a particular cultural knowledge that they themselves had received from their own parents. On the contrary, Shafik's parents and grandparents do not even seem to know the term "Amazigh", let alone any related movement. What is relevant instead is an intragenerational interaction in the aftermath of said geography lesson, since it was a cousin of Shafik's who apparently offered a new framework to reflect his experiences of discrimination and participate in the construction of the Imazighen as an imagined community (Anderson 1983) beyond the confines of his own family or community.

\section{Politicization at University}

After finishing high school, Shafik moved to Meknes and later to Oujda to study at university, where he soon joined the Amazigh movement (Movement Culturel Amazigh, MCA), a movement resisting the 
political and socio-economic marginalization of the Amazigh population and promoting recognition of their culture and which has, for instance, campaigned for the recognition of Tamazight as an official Moroccan language with relative success. Shafik relates how he met the local MCA discussion group and soon decided to actively join the movement. He mentions other political student associations, namely the leftwing "Basist Path" faction and the Islamist faction, and goes on to describe the sometimes-violent confrontations between them and Amazigh activists. Confrontations between these three groups are common at universities throughout Morocco, sometimes even resulting in student deaths (Silverstein and Crawford 2004; Zerhouni 2018). Shafik relates how in Meknes a student had died in one such clash, and that he himself felt unsafe on his way to university since he was known as an MCA activist. He presents himself as someone who is "rather quiet" and not prone to violence, emphasizing that he and his fellow activists organized several activities encouraging students to abstain from violence: "We organized cultural days which were also intended to tell our activists that the university is based on ideas, not violence." A certain continuity is evident here, in the sense that throughout his life story, the problem of peer violence in educational institutions-now in a politicized form-remains a relevant problem in his narration.

\section{After University: Politics and Precariousness}

After finishing his mathematics degree in 2011, Shafik started looking for a job, without success. After three years of precarious employment and "bricolage," as he describes his daily struggle to make ends meet with informal, precarious jobs, Shafik decided to register for a Ph.D. in mathematics. In Morocco, the unemployment rate among educated young people is even higher than among the lesseducated, which is why Bennani-Chraïbi (2000, 143), already two decades ago considered the integration of the educated urban young "the most pressing problem in Morocco today." Since then, and 
particularly since 2010, things have deteriorated, with unemployment rates of over 20 per cent for people aged between 15 and 24 as the national average, and even over 45 per cent in urban regions (Medias24 2017; World Bank 2012). The Moroccan Diplômés Chômeurs, or Unemployed Graduates Movement, addresses this issue in its own way, and Shafik's trajectory on joining the movement soon after receiving his Master's degree can be seen as typical. The movement regularly stages protests, usually in front of the parliament building in Rabat, demanding public-sector employment from the government. Diplômés Chômeurs is an "apolitical" movement (Emperador Badimón 2011), in that it does not make further demands for political change, but has a narrow focus: their activists' presumed right to employment in the public sector and the protest against the nepotism and patronage practices that exclude them from such employment. In the past, the movement's mobilizations often resulted in effective negotiations with the government, which, drawing on repression as well as co-optation, occasionally employed some of the activists in the public sector; for this purpose, local Diplômés Chômeurs committees pass their members' list to the respective ministry. Elected committee coordinators moreover monitor their members, noting their presence at protests and making sure that only those who regularly and actively participate are given a job. Activists are given tokens that they have to return to their local coordinator after a demonstration (Bogaert and Emperador Badimón 2011; Emperador Badimón 2007, 2009). Apart from this characteristic feature, the movement's repertoire of collective action (McAdam et al. 2001; Tilly 1986) is undoubtedly inherited from the Moroccan Leftist movement and can be traced back to Moroccan student unions in the late 1980's (Emperador Badimón 2011; Rachik 2010, 26; Sater 2007, 94). However, precisely because of its "apolitical" character, the unemployed graduate movement represents an ideologically very open movement which, from the very beginning, has allowed not only Leftists but also Islamists, Amazigh activists, and non-partisan graduates to participate.

So, whereas the violence between different political factions does not seem to be an issue at this stage in Shafik's life story, there is a thematic continuity in that there are many accounts of police violence 
during Diplômés Chômeurs protests. For some local Diplômés Chômeurs committees, exposure to police violence is even an explicit part of the "meritocratic" monitoring process: activists who expose themselves more directly to police violence during sit-ins, for example by forming the front row, are given a higher ranking on the list that the coordinators pass on to the government should the negotiations for jobs prove successful. ${ }^{5}$

Since Shafik joined the movement he has frequently protested in front of the parliament building in Rabat, demanding a job in the public sector. But since the change of government in 2011, he tells me, the prospect of this is rather dim, as succeeding governments have explicitly refused to abide by agreements that the movement signed with the previous government. At the time of my interview with Shafik he was in receipt of a government Ph.D. scholarship of 1000 MAD (around US\$95) a month and was working in the informal private sector as a freelance tutor to cover his living costs in Rabat. He frequently describes his livelihood strategy as a sequence of precarious jobs, a "bricolage." At the time of the interview he was sharing a rented rooftop room measuring approximately $18 \mathrm{~m}^{2}$ in a poor neighborhood on the outskirts of Rabat with three other Ph.D. students; apparently his family is unable to support him, and in any case he would refuse their support because he would not consider it appropriate at his age.

To begin with, Shafik hid his activism in the Amazigh and the Unemployed Graduate Movement from his parents and his family, as they would fear the repercussions. When asked if he has discussed questions of politics of social justice with his family, he says:

When I discuss politics with my father, my uncle or my grandparents, all they talk about is the makhzen [the monarchy and its tightly-knit network of repression, control and patronage] or the King. They say: "Be quiet, be quiet-the walls have ears, they'll hear us," because they're closer to the colonial era, and they say it's very good that the King came to power, because before there was only war, and afterwards there was peace. "When you're in the desert, you don't need justice," they say.

5 Personal communication with an activist, November 2014. 
On the one hand, this passage describes the intergenerational transmission of fear of violent reprisals by the regime. These fears are clearly the result of the historical experience of colonialism and Morocco's transition to independence, as well as of the notorious "Years of Lead," the period with the most violent repression, under Hassan II (r. 1961-1999). On the other hand, this scene, and markers of spatial difference such as "if you live in the desert," offer another account of incommunicability in Shafik's current situation and his strategy for achieving political change through the Amazigh movement and improving his socio-economic situation via the Diplomés Chômeurs movement. Shafik may feel the fear passed on by the older generation very clearly, but due to his different situation he feels compelled to resist succumbing to it.

When asked what he would do if he were given the public-sector job he is currently reclaiming, he says first that he wants to provide for his family to reciprocate all they have given him, and especially to provide for his younger brothers and sisters. In addition, he would dedicate himself more to the Amazigh movement's struggle. But then he returns to the question of providing for his family, and mentions that he has bought books for his younger siblings "so that they don't feel inferior." When asked directly about plans to have a family of his own, he answers that this is a rather low priority: "Maybe in four years, once I have a publicsector job." He reiterates that the most pressing issue is providing for his siblings.

In a follow-up interview in September 2015, Shafik explained that he had left the Diplômés Chômeurs movement because he saw no future in it with the current government's continued reluctance to honor the agreement signed with the prior government. He tells me that his younger brother quit school at the age of 14. Although Shafik had tried to talk him out of it and to discover the reason for his reluctance to continue his education, his brother would not tell him what was going on in school. Shafik tried to take him to a public service psychologist in a city a day's journey away, but found the waiting room full of "really crazy people" waiting for a doctor who never arrived. He gave up the idea of consulting a psychologist and they returned to their hometown. 


\section{Discussion: Intergenerational Disparity, Peer Violence, and the Production of the Precariat}

Shafik's life story provides an impressive account of the social change to which Moroccan nomads have been subject in recent decades: the son of illiterate parents, he is currently pursuing a Ph.D. in mathematics. This could be presented as an educational success story involving outstanding social mobility and thus as an example of upward mobility, as often found in normative narrations of "development" and "progress." But already on this manifest level it is clear that the next step in his career does not seem to be the result of a choice from a variety of options but is propelled by a different dynamic: the fact that he cannot find a suitable, stable job, and thus feels obliged to continue his education, not least since his Ph.D. studies give him access to a modest scholarship. So far, his career has not brought him social mobility in the form of employment that allows him to make long-term future plans and provide for his family as he wishes.

If we understand modern educational institutions as the focal point of the organized intergenerational transmission of knowledge, embodied routines, and social norms, a key question regarding social change is to what extent pupils and students in schools and universities are institutionally allowed and encouraged to appropriate and creatively deal with the knowledge and norms that are passed on to them, or are encouraged to reinterpret them so that they can experience society as changeable and conceive of themselves as potential agents of social change.

What is telling in Shafik's life story is firstly, a surprising absence of scenes of generativity, in the sense of care by the older generation (Erikson 1959). There are hardly episodes of intergenerational interaction that would allow him to appropriate, reflect, and reinterpret the societal knowledge and norms that have been passed on to him. His first day at school, when he was dropped off by his father and left alone, in this sense functions as the onset of a more general pattern that permeates the ensuing narration and is also found in the intergenerational relationships within the family, but even more so in state institutions; i.e., in students' interactions with teachers and professors. As stated, the only member of staff mentioned in the whole of his educational trajectory 
is the elementary school teacher who evicted his aunt from the school. Secondly, Shafik describes all of the official educational institutions that he attended first and foremost as spaces of danger and humiliation, and more precisely, of peer violence-first among his classmates in elementary school, and later as physical altercations between political factions, even resulting in the death of one student. In this regard, his aunt and grandmother's intervention in elementary school can be read as an important act of intergenerational transmission of an attitude of resistance. Since this is the only event mentioned that would disrupt the pattern of intergenerational neglect, the memory of this event seems to be a key resource for later political action; since it is described in such detail and summed up with the statement "they always defended me," it illustrates a very caring relationship. However, this relationship appears to be so important to Shafik precisely because in his life story are the only persons who would intervene to put an end to this bullying by directly mirroring the violence. Staff toleration of peer violence, whether in school or university, is obviously a marker of institutional neglect. In this situation, the university students themselves have to find a way of negotiating and managing conflict. After leaving university, this pattern continued in Shafik's life with the police violence to which the Diplômés Chômeurs activists are exposed, intentionally taking this risk into account and even including the violence they suffer in their quantified system of meritocracy, which is reflected in their membership list.

Shafik's characteristic experience of social change, then, is socioeconomic and physical precariousness or vulnerability, which seem closely linked to the generational disparity that this group is experiencing. Analytically, we can speak of a generational disparity in the sense not only of his family choosing that Shafik should take on a different life project to their own, but also that this disparity from members of the older generation in the family has not been mended, since there is no account of coming to an understanding with regard to the difference of experiences in their everyday life. On a political level, this is echoed in the incommunicability of his political activism. As nomads, his family continues to live in relative poverty, although not in urban precariousness, so they see no socio-economic benefit in organizing themselves in ways similar to Shafik's political activism. The respective passage cited 
above thus once more highlights generational disparity, since their experiences, frames for action and ensuing patterns of interpretation differ to the extent of incommunicability, and apparently Shafik does not even try to help them to understand his actions.

It is telling that Shafik's hopes of secure, public employment first and foremost involve using his experience in the educational system to support his younger brother, who is currently attending high school. Shafik obviously aims to exercise generativity. However, the incommunicability between the older family members and himself seems to be reproduced in this relationship: whereas Shafik as a pupil at least talked to his aunt seeking help and solace, his younger brother is apparently unwilling or unable to describe his experiences and difficulties in school. Shafik apparently aims to offer his brother dedicated support, similar to that which he received from his aunt and grandmother, but including guidance and psychosocial generativity that is more adapted to the symbolic realm of a school setting. In consequence, Shafik takes his brother to a psychologist far away, an act that can be read as a search for a "translator" to bridge the incommunicability. But this episode of the life story is characterized by an almost Kafkaesque ending that epitomizes the futility of looking for advice on adequate forms of familial care, since the doctor simply does not show up and Shafik and his brother are left in the waiting room with "very crazy people" until they give up and return home.

\section{Concluding Remarks}

This chapter aimed to illustrate generational analysis in the life story approach as a method for researching social change, based on the indepth analysis of a single case. The social change described in life stories such as Shafik's is the production of an academic precariat with a rural background and clear generational contours. Empirically, this becomes accessible through a focus on life-story narrations and analysis of the intergenerational relationships that these convey. After his first days in school, and the resolute intervention of his aunt and grandmother, the only significant others in Shafik's political socialization are other 
members of his own, precarious generation: fellow Amazigh students, and MCA and Diplômés Chômeurs activists, many of them also the sons and daughters of nomads, peasants, and rural artisans facing the exclusive and largely saturated labor market in Moroccan cities in their search of a stable job. Departing from cases such as Shafik's, the Diplômés Chômeurs movement in particular can be seen as a strategy of a precarious generational unit (Mannheim 1952) for forming intragenerational networks of trust and negotiating their social mobility and concomitant transition to adulthood, as it is socioculturally defined in this context, with a semiauthoritarian, "hybrid regime" (Desrues 2013). Whereas the Diplômés Chômeurs movement is surely an agent of change, it is also apolitical in the sense that it does not demand further social and political change. The Amazigh movement, in turn, appears to be the context in which Shafik develops a political vision for wider society, and here, too, most of the activists I met had a rural background and considered the Amazigh movement an adequate expression of their demands for change.

\section{Bibliography}

Aït Mous, Fadma. 2011. "Les enjeux de l'amazighité au Maroc." Confluences Méditerranée 78 (21): 121-31.

Anderson, Benedict R. 1983. Imagined Communities: Reflections on the Origin and Spread of Nationalism. London: Verso.

Apitzsch, Ursula, Lena Inowlocki, and Maria Kontos. 2008. "The Method of Biographical Policy Evaluation.” In Self-Employment Activities of Women and Minorities: Their Success or Failure in Relation to Social Citizenship Policies, edited by Ursula Apitzsch, 13-23. Wiesbaden: VS.

Benei, Veronique. 2010. "To Fairly Tell: Social Mobility, Life Histories, and the Anthropologist." Compare: A Journal of Comparative and International Education 40 (2): 199-212.

Bennani-Chraibi, Mounia. 2000. "Youth in Morocco: An Indicator of a Changing Society." In Alienation or Integration of Arab Youth: Between Family State and Street, edited by Roel Meijer, 143-60. Richmond: Curzon. 
Bertaux, Daniel. 1976. Histoires de vies - ou récits de pratiques? Méthodologie de l'approche biographique en sociologie. Rapport au CORDES. Paris: Maison des sciences de l'homme.

Bertaux, Daniel. 1997. Le récit de vie. Paris: Colin.

Bertaux, Daniel, and Paul Thompson. 1993. "Introduction.” In Between Generations: Family Models, Myths \& Memories, edited by Daniel Bertaux and Paul Thompson. Memory and Narrative Series, 1-12. New Brunswick, NJ: Transaction Publishers.

Bogaert, Koenraad, and Montserrat Emperador Badimón. 2011. "Imagining the State Through Social Protest: State Reformation and the Mobilizations of Unemployed Graduates in Morocco." Mediterranean Politics 16: 241-59. Bourdieu, Pierre. (1986) 2004. “The Biographical Illusion.” In Identity: A reader, edited by Paul Du Gay, Jessica Evans, and Peter Redman, 297-303. London and Thousand Oaks: Sage.

Bourdieu, Pierre. 1993a. "The Contradictions of Inheritance." In The Weight of the World, edited by Pierre Bourdieu, 507-13. Stanford: Stanford University Press.

Bourdieu, Pierre, ed. 1993b. The Weight of the World. Stanford: Stanford University Press.

Delcroix, Catherine. 2005. Ombres et lumières de la famille Nour: Comment certains résistent face à la précarité. Paris: Payot \& Rivages.

Desrues, Thierry. 2013. "Mobilizations in a Hybrid Regime: The $20^{\text {th }}$ February Movement and the Moroccan Regime." Current Sociology 61 (4): 409-23.

Emperador Badimón, Montserrat. 2007. "Diplômés chômeurs au Maroc: dynamiques de pérennisation d'une action collective plurielle." L'Année du Maghreb 3: 297-311.

Emperador Badimón, Montserrat. 2009. "Les manifestations des diplômés chômeurs au Maroc: la rue comme espace de négociation du tolérable." Genèses 3 (77): 30-50.

Emperador Badimón, Montserrat. 2011. "Unemployed Moroccan University Graduates and Strategies for 'Apolitical' Mobilization.” In Social Movements, Mobilization, and Contestation in the Middle East and North Africa, edited by Joel Beinin and Frédéric Vairel, 217-35. Stanford: Stanford University Press.

Erikson, Erik H. 1959. Identity and the Life Cycle. New York: Norton.

Maddy-Weitzman, Bruce. 2011. The Berber Identity Movement and the Challenge to North African States. Austin: University of Texas Press. 
Mannheim, Karl. (1928) 1952. "The Problem of Generations." In Essays on the Sociology of Culture, edited by Karl Mannheim, 276-322. London: Routledge.

McAdam, Doug G., Sidney G. Tarrow, and Charles Tilly. 2001. Dynamics of Contention. Cambridge: Cambridge University Press.

Medias24. 2017. "Le chômage des jeunes dans les villes dépasse 45\% pour la première fois." Available online at https://www.medias24.com/MAROC/ ECONOMIE/ECONOMIE/177926-Maroc.-Le-chomage-des-jeunes-dansles-villes-depasse-45-pour-la-premiere-fois.html, checked on May 27, 2019.

Rachik, Abderrahmane. 2010. "Nouveaux mouvements sociaux et protestations au Maroc.” http://www.ires.ma/sites/default/files/nouveaux_mouvem ents_sociaux_et_protestations_au_maroc.pdf?access=1. Accessed February 14, 2014.

Riemann, Gerhard. 1986. "Einige Anmerkungen dazu, wie und unter welchen Bedingungen das Argumentationsschema in biographisch-narrativen Interviews dominant werden kann." In Sozialstruktur und soziale Typik, edited by Hans-Georg Soeffner, 112-57. Frankfurt and New York: Campus.

Riemann, Gerhard. 1987. Das Fremdwerden der eigenen Biographie: Narrative Interviews mit psychiatrischen Patienten. München: W. Fink.

Rosenthal, Gabriele. 1993. "Reconstruction of Life Stories: Principles of Selection in Generating Stories for Narrative Biographical Interviews." The Narrative Study of Lives 1 (1): 59-91.

Rosenthal, Gabriele. 1995. Erlebte und erzählte Lebensgeschichte: Gestalt und Struktur biographischer Selbstbeschreibungen. Frankfurt/Main and New York: Campus.

Rosenthal, Gabriele, ed. 2009. Ethnicity, Belonging and Biography: Ethnographical and Biographical Perspectives. Münster: Lit.

Sater, James N. 2007. Civil Society and Political Change in Morocco. London and New York: Routledge.

Schwarz, Christoph H. 2017. “'Generation in Waiting' or 'Precarious Generation'? Conceptual Reflections on the Biographical Trajectories of Unemployed Graduates Activists in Morocco." In Neoliberalism, Austerity, and the Moral Economies of Young People's Health and Wellbeing, edited by Peter Kelly and Joanne Pike, 313-32. London: Palgrave Macmillan.

Schwarz, Christoph H. 2019. "Political Socialization and Intergenerational Transmission: Life Stories of Young Social Movement Activists in Morocco." Journal of North African Studies 25 (1): 1-25. 
Schütze, Fritz. 1977. Die Technik des narrativen Interviews in Interaktionsfeldstudien dargestellt an einem Projekt zur Erforschung von kommunalen Machtstrukturen. Bielefeld: Univ. Bielefeld, Fak. für Soziologie.

Schütze, Fritz, and Gerhard Riemann. 1991. “'Trajectory' as a Basic Theoretical Concept for Analyzing Suffering and Disorderly Social Processes.” In Social Organization and Social Process: Essays in Honor of Anselm Strauss, edited by David R. Maines, 333-57. New York: de Gruyter.

Silverstein, Paul A., and David Crawford. 2004. "Amazigh Activism and the Moroccan State." Middle East Report 233: 44-48.

Standing, Guy. 2011. The Precariat. London: Bloomsbury Academic.

Thompson, Paul. 1981. "Life Histories and the Analysis of Social Change." In Biography and Society: The Life History Approach in the Social Science, edited by Daniel Bertaux, 289-306. London: Sage.

Tilly, Charles. 1986. The Contentious French. Cambridge, MA: Harvard University Press.

World Bank. 2012. "Promoting Youth Opportunities and Participation." Report No. 68731. Available online at http://documents.worldbank.org/cur ated/en/507941468109463283/Morocco-Promoting-youth-opportunitiesand-participation. Accessed May 26, 2019.

Zerhouni, Saloua. 2018. "Violences en milieu universitaire au Maroc. Les limites de la répression face à une violence multiforme." Available online at www.rssi-rabat.ma/wp-content/uploads/2019/01/Violence-en-milieu-Uni versitaire-au-Maroc.pdf. Accessed April 15, 2019. 
Open Access This chapter is licensed under the terms of the Creative Commons Attribution 4.0 International License (http://creativecommons.org/ licenses/by/4.0/), which permits use, sharing, adaptation, distribution and reproduction in any medium or format, as long as you give appropriate credit to the original author(s) and the source, provide a link to the Creative Commons license and indicate if changes were made.

The images or other third party material in this chapter are included in the chapter's Creative Commons license, unless indicated otherwise in a credit line to the material. If material is not included in the chapter's Creative Commons license and your intended use is not permitted by statutory regulation or exceeds the permitted use, you will need to obtain permission directly from the copyright holder.

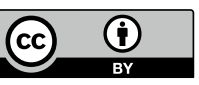

